\title{
KADAR LOGAM BERAT TEMBAGA (Cu), KROMIUM (Cr) PADA SEDIMEN DAN JARINGAN LUNAK Anadara granosa DI PERAIRAN TAMBAK LOROK SEMARANG
}

Contents of heavy metals copper (Cu), chromium (Cr) in Sediments and Soft Tissue Anadara granosa in Water of Tambak Lorok Semarang

\section{Mayda Anggita Dewi, Djoko Suprapto*) dan Siti Rudiyanti}

Program Studi Manajemen Sumberdaya Perairan Departemen Sumberdaya Akuatik

Fakultas Perikanan dan Ilmu Kelautan Universitas Diponegoro

Jl. Prof. Soedarto, SH, Tembalang, Semarang, Jawa Tengah - 50275, Telp/Fax. +6224 7474698

Email : mayda.anggita27@gmail.com

\begin{abstract}
ABSTRAK
Perkembangan industri di Semarang memiliki dampak positif bagi kesejahteraan masyarakat dan dampak negatif bagi kehidupan A. granosa. Penelitian ini dilaksanakan pada bulan Oktober 2016 hingga Februari 2017 dengan tujuan untuk mengetahui kadar logam $\mathrm{Cu}$ dan $\mathrm{Cr}$ pada air, sedimen, A. granosa serta nilai MTI (Maximum Tolerable Intake) di perairan Tambak Lorok, Semarang. Lokasi sampling ditetapkan secara purpose sampling, kandar $\mathrm{Cu}, \mathrm{Cr}$ pada air laut menggunakan acuan APHA 1992, sedimen mengacu US.EPA 1996, A. granosa berdasarkan AOAC 2012. Hasil penelitian memperoleh pada air kadar $\mathrm{Cu}<0,001 \mathrm{mg} / \mathrm{L}-0,002 \mathrm{mg} / \mathrm{L}$ dan $\mathrm{Cr}<0,001 \mathrm{mg} / \mathrm{L}-<0,003 \mathrm{mg} / \mathrm{L}$, pada sedimen kadar $\mathrm{Cu} 37,13 \mathrm{mg} / \mathrm{kg}$ - 49,41 mg/kg dan Cr 22,65 mg/kg - 29,25 mg/kg, pada A. granosa kadar Cu 0,43 mg/kg - 1,48 $\mathrm{mg} / \mathrm{kg}$ dan $\mathrm{Cr} 0,44 \mathrm{mg} / \mathrm{kg}-1,48 \mathrm{mg} / \mathrm{kg}$. Analisis hasil pengukuran logam $\mathrm{Cu}, \mathrm{Cr}$ pada air laut menurut Kep.Men.LH nomor 51 tahun 2004 tidak melebihi baku mutu. pegukuran $\mathrm{Cu}$ dan $\mathrm{Cr}$ pada sedimen telah melampaui batas yang diterapkan NOAA 1999. A. granosa telah tercemari oleh logam $\mathrm{Cu}$ maupun $\mathrm{Cr}$ dan nilai MTI untuk logam $\mathrm{Cu}$ yaitu 0,187 gram per minggu serta 0,002 gram per minggu untuk logam $\mathrm{Cr}$.
\end{abstract}

Kata Kunci: Logam berat $\mathrm{Cu}$; Cr; Anadara granosa; air laut; sedimen

\section{ABSTRACT}

Industrial development in Semarang has positive impact on people's welfare and negative impact on life A. granosa. This study was conducted on October 2016 until Februari 2017 with the aim to know the levels of Cu and Cr metals in water, sediment, A. granosa and the valve if MTI in water of Tambak Lorok, Semarang. The sampling location is set purpose sampling, levels of $\mathrm{Cu}$ and $\mathrm{Cr}$ in sea water using APHA 1992, sediment refers to US. EPA 1996, A.granosa based on AOAC 2012. The results of the research obtained Cu levels in water $<0,001 \mathrm{mg} / \mathrm{L}-0,002 \mathrm{mg} / \mathrm{L}, \mathrm{Cr}<0,001-$ $<0,003 \mathrm{mg} / \mathrm{L}$, on $\mathrm{Cu}$ sediment $37,13 \mathrm{mg} / \mathrm{kg}-49,41 \mathrm{mg} / \mathrm{kg}$, Cr levels in sediment 22,65 mg/kg - 29,25 mg/kg, on A. granosa Cu levels $0,43 \mathrm{mg} / \mathrm{kg}-1,48 \mathrm{mg} / \mathrm{kg}$ and $\mathrm{Cr}$ levels $0,44 \mathrm{mg} / \mathrm{kg}-1,48 \mathrm{mg} / \mathrm{kg}$. Analysis of the results of measurement of $\mathrm{Cu}, \mathrm{Cr}$ at sea water according to Kep.Men.LH number 51 of 2004 not exceeding the quality standard. The measurement of $\mathrm{Cu}$ and $\mathrm{Cr}$ on sediments has exceeded the limits applied by NOAA 1999. A. granosa has been contaminated by both $\mathrm{Cu}$ and $\mathrm{Cr}$ metals and the MTI value for Cu metals is 0.187 grams/week also 0.002 grams/week for $\mathrm{Cr}$.

Keywords: Cu; Cr; Anadara granosa; sea water; sediment

*) Penulis Penanggungjawab 


\section{PENDAHULUAN}

Perkembangan industri di Kota Semarang memiliki dampak yang positif bagi kesejahteraan masyarakat seperti penyediaan lapang pekerjaan namun juga memiliki dampak negatif dengan peningkatan jumlah limbah dihasilkan dalam bentuk gas, padat dan cair serta berbahaya bagi lingkungan ekosistem.

Anadara granosa merupakan hewan laut jenis kekerangan yang disukai oleh masyarakat kota Semarang memiliki gizi yang tinggi seperti protein sebesar $19,48 \%$, air $74,37 \%$, dan lemak $2,48 \%$ pada daging kerang darah rebus, sedangkan kandungan protein sebesar 23,23\%, air 65,69\%, dan lemak 7,01\% dalam keadaan mentah (Nurjanah et al.,2005 dalam Anggraini, 2016). Terlepas dari kelebihannya, kerang darah mendapatkan makanan dari perairan yang tercemar, sehingga tubuhnya juga terpengaruh dan jika dikonsumsi manusia akan berakumulasi di dalam tubuh serta akan menjadi zat toksik yang akan membahayakan manusia.

Kerang darah yang dikenal sebagai cockle ini merupakan kelompok kerang yang memiliki belahan cangkang yang melekat satu sama lain pada batas cangkang. Lapisan luar cangkang umumnya berwarna putih dan berselaputkan suatu lapisan berwarna kecokelatan. Disebut kerang darah karena kelompok kerang ini memiliki pigmen darah merah atau haemoglobin yang disebut bloody cockles, sehingga kerang ini dapat hidup pada kondisi kadar oksigen yang relatif rendah.

Perairan Tambak Lorok merupakan perairan utara laut Jawa Tengah yang menjadi jalur penangkapan ikan dan adanya buangan limbah pabrik industri di aliran sungai yang menjadi salah satu sumber pencemar logam berat (tembaga serta kromium), yang akan diserap di dalam tubuh biota dari hasil tangkapan (kerang darah) di Kota Semarang. Selain penghasil produk perikanan, perairan ini juga tempat berbagai buangan sisa hasil perikanan dari TPI (Tempat Pelelangan Ikan), rumah tangga, industri, penyedotan dan pembungan air dari PLTU, serta air balas sekitar pelabuhan yang mengandung pencemar yang dapat mengganggu kesehatan. Sesuai hasil survei Dinas Perindustrian dan Perdagangan Kota Semarang (2008) dalam Feriano et al. (2013), Kawasan Perairan Pantai Semarang Timur terdapat berbagai industri yang potensial penghasil limbah seperti tekstil, plastik, bengkel, logam, penampungan batu bara, dan kertas.

Tujuan dari penelitian ini adalah

1. Mengetahui kadar logam tembaga dan kromium pada air laut;

2. Mengetahui kadar logam tembaga dan kromium pada sedimen;

3. Mengetahui kadar logam tembaga dan kromium pada jaringan lunak A. granosa;

4. Mengetahui jumlah MTI (Maximum Tolerable Intake) untuk A. granosa di perairan Tambak Lorok, Semarang.

\section{MATERI DAN METODE PENELITIAN}

\section{Materi}

Penelitian dilakukan di perairan Tambak Lorok Semarang, pada bulan Oktober 2016 sampai bulan Februari 2017 guna pengambilan sampel untuk mengetahui kadar logam berat yang ada di perairan dengan menggunakan 3 stasiun dengan kedalaman yang berbeda sesuai dengan kebiasaan nelayan kerang darah untuk melaut yaitu $5 \mathrm{~m}, 7,1 \mathrm{~m}$ dan 8,25 (Gambar 1). Kemudian analisis sampel dilakukan di Laboratorium Balai Besar Teknologi Pencegahan Pencemaran Industri (BBTPPI) Semarang dengan menggunakan metode analisis AAS.

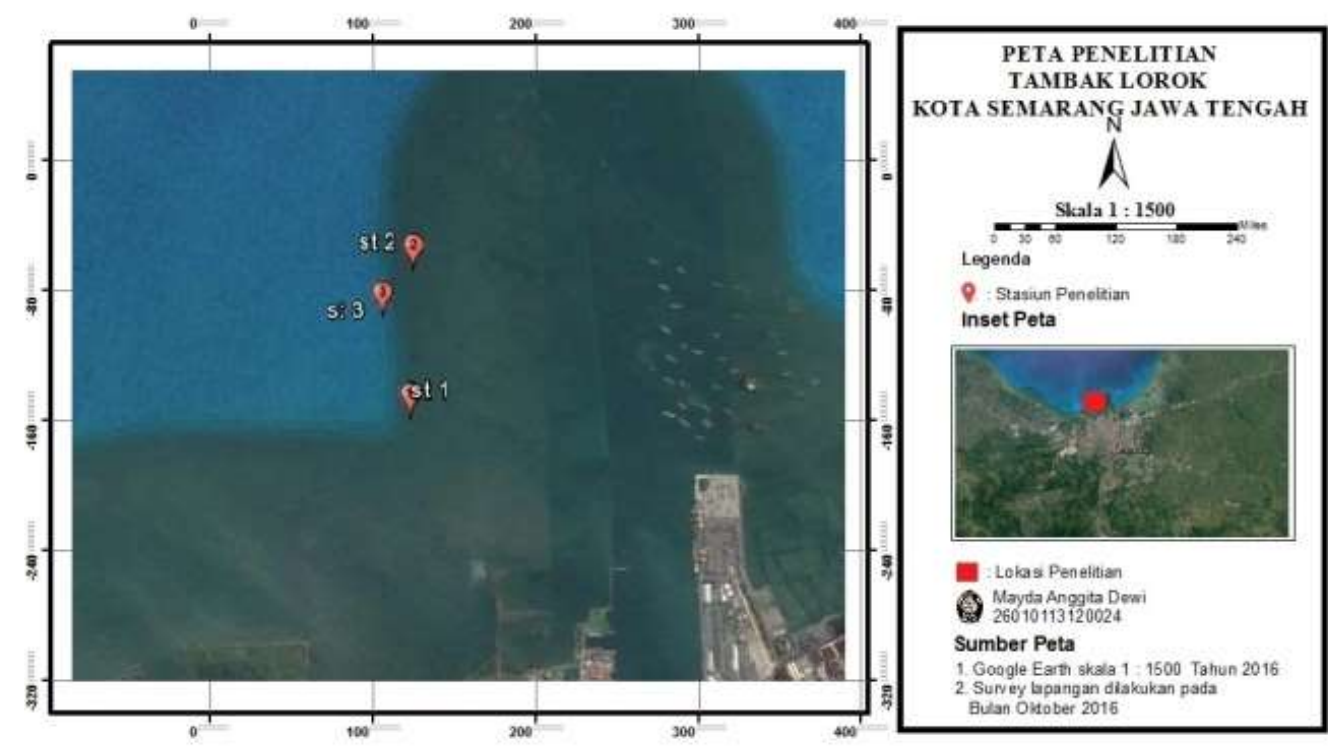

Gambar 1. Denah lokasi pengambilan sampel di Laut Tambak Lorok Semarang 
Tabel 1. Kondisi Stasiun Pengamatan

\begin{tabular}{|c|c|c|}
\hline Stasiun & Koordinat & Lokasi \& Deskripsi Stasiun Pengamatan \\
\hline I & $\begin{array}{l}6^{\circ} 55^{\prime} 58,00^{\prime \prime} \mathrm{LS} \\
110^{\circ} 24,26,00^{\prime \prime} \mathrm{BT}\end{array}$ & $\begin{array}{l}\text { Berada ditempat terdekat dengan muara perairan Tambak Lorok yang } \\
\text { memiliki kedalaman } 5 \text { meter, terdapat banyak kapal nelayan yang } \\
\text { berlalu-lalang. Air laut berwarna biru sedikit coklat, ada lapisan } \\
\text { minyak dipermukaan air serta terdapat banyak sampah rumah tangga } \\
\text { berupa botol plastik, kantong plastik, jaring. Jarak antara stasiun } 1 \text { ke } \\
\text { stasiun } 2 \text { sejauh } 1 \mathrm{~km} \text {. }\end{array}$ \\
\hline II & $\begin{array}{l}6^{\circ} 55^{\prime} 25,60^{\prime \prime} \mathrm{LS} \\
110^{\circ} 24^{\prime} 26,00^{\prime \prime} \mathrm{BT}\end{array}$ & $\begin{array}{l}\text { Letak yang paling jauh dari daratan tetapi berdekatan dengan kapal- } \\
\text { kapal tengker yang menunggu antrian untuk bongkar muat barang di } \\
\text { Pelabuhan Tanjung Mas Semarang. Perairan berwarna biru, terdapat } \\
\text { sedikit sampah rumah tangga serta ada lapisan minyak dipermukaan } \\
\text { air. Jarak antara stasiun } 2 \text { ke stasiun } 3 \text { sejauh } 1 \mathrm{~km} \text {. }\end{array}$ \\
\hline III & $\begin{array}{l}6^{\circ} 55^{\prime} 36.10^{\prime \prime} \mathrm{LS} \\
110^{\circ} 24^{\prime} 19.40^{\prime \prime} \mathrm{BT}\end{array}$ & $\begin{array}{l}\text { Berdekatan dengan Pelabuhan Tanjung Mas, memiliki kedalaman } \\
8,25 \text { meter serta lapisan minyak dipermukaan air. Tidak terdapat } \\
\text { sampah rumah tangga, air laut terlihat biru tua. }\end{array}$ \\
\hline
\end{tabular}

Kerang darah diambil menggunakan jaring arad, sampel air dengan botol nansen, serta sempel sedimen dengan grab. Kemudian dimasukkan dalam wadah. Penanganan khusus guna pengawetan dilakukan pada air yang diberi $\mathrm{HNO}_{3}$ hingga $\mathrm{pH}>2$ serta kerang darah yang telah dikupas langsung dimasukkan ke pendingin dengan tujuan untuk mempermudah dalam pengujian kadar logam $\mathrm{Cu}$ dan $\mathrm{Cr}$ serta parameter kimia fisika yang diukur berupa temperature, salinitas, $\mathrm{DO}, \mathrm{pH}$, arus.

\section{Metode}

Pengumpulan data penelitian menggunakan metode observasi, metode observasi adalah suatu metode yang dilakukan dengan pengamatan dan pencatatan secara sistematis baik langsung maupun tidak langsung mengenai kejadian-kejadian yang sedang diselidiki (Hadi, 1980 dalam Partogi et al., 2014).

Metode pengambilan sampel dilakukan secara purposive sampling dengan pertimbangan pemilih lokasi-lokasi yang merupakan tempat hidup A. granosa (L.) (shellfish bed), berdasarkan informasi dari nelayan perairan Tambak Lorok Semarang. Pengukuran parameter kualitas air dilakukan secara in situ (Taurusiana et al,. 2014).

Pengambilan A. granosa menggunakan jaring arad nelayan yang langsung ke dasar perairan pada 3 stasiun menurut kedalaman ( 5 meter, 7,1 meter dan 8,25 meter) pada bulan Oktober 2016 dan Februari 2017. Biota yang selalu terendam di dasar perairan diambil jaringan lunaknya minimal memiliki berat 500 gram per stasiun.

Analisa logam (Cu dan Cr) dalam air mengacu pada APHA, 1992, sedimen menggunakan US.EPA 1996 dan A. granosa berdasarkan Latimer, 2012 dilakukan di laboratorium dengan metode uji mengacu pada EPHA Berat maksimal dalam konsumsi tiap minggunya menggunakan nilai Maxsimum Tolerable Intake (MTI) dihitung dengan perumusan:

$$
\mathrm{MTI}=\mathrm{MWI} / \mathrm{Ct}
$$

Keterangan:

MWI : Maksimum Weekly Intake ( $\mu \mathrm{g}$ untuk orang dengan berat badan $60 \mathrm{~kg}$ per minggu)

$\mathrm{Ct} \quad$ : Konsentrasi rata- rata logam berat yang ditemukan di dalam jaringan lunak kerang ( $\mu \mathrm{g}$ per gram)

Batas maksimum konsentrasi dari bahan pangan terkonsentrasi logam berat yang boleh dikonsumsi per minggu (Maximum Weekly Intake) menggunakan angka ambang batas yang diterbitkan oleh organisasi dan lembaga pangan internasional World Health Organization (WHO) dan Joint FAO/WHO Expert Committee on Food Additive (JEFCA). Perhitungan Maximum Weekly Intake menggunakan rumus:

$$
\text { MWI }(\mathrm{g})=\text { Berat badan }^{\mathrm{a})} \mathrm{x} \text { PTWI }^{\mathrm{b})}
$$

Keterangan:

a): untuk asumsi berat badan sebesar $60 \mathrm{~kg}$;

b): PTWI Provisional Tolerable Weekly Intake (angka toleransi batas maksimum per minggu) yang dikeluarkan lembaga pangan terkait dalam satuan $\mu$ per kg berat badan yang ditampilkan pada Tabel 2. 
Tabel 2. Angka Toleransi Batas Konsumsi Maksimum Per Minggu yang Diterbitkan Badan JEFCA dan WHO

\begin{tabular}{lc}
\hline Jenis Logam & $\begin{array}{l}\text { PTWI }(\boldsymbol{\mu g} / \mathbf{k g} \text { Berat } \\
\text { Badan }) \text { per Minggu }\end{array}$ \\
\hline $\mathrm{Cu}$ & $3500^{\mathrm{a})}$ \\
$\mathrm{Cr}$ & $23,3^{\mathrm{b})}$ \\
\hline
\end{tabular}

Keterangan:

a): JEFCA dalam FAO/WHO (2004);

b): WHO dalam Zazouli et al. (2006).

\section{Analisis Data}

Data kadar logam berat $\mathrm{Cu}, \mathrm{Cr}$ dibandingkan dengan baku mutu untuk kehidupan biota laut sesuai Kep. Men.L.H nomor 51 tahun 2004. Data hasil pengukuran kadar logam berat $\mathrm{Cu}$ dan $\mathrm{Cr}$ pada sedimen akan dibandingan dengan standar baku mutu dari NOAA oleh Buchman (1999). Data kadar logam pada A. granosa diamati dan dianalisis nilai Maximum Tolerable Intake (MTI) untuk mengetahui berat maksimal asupan jaringan lunak kerang darah yang aman dikonsumsi per minggu (untuk individu dengan berat badan $60 \mathrm{~kg}$ ).

\section{HASIL DAN PEMBAHASAN \\ Hasil \\ Deskripsi Wilayah Kajian}

Lokasi pengambilan sampel $A$. granosa di perairan Tambak Lorok Semarang yang memiliki kedalaman antara 5 meter sampai 8,25 meter, berdekatan dengan terminal bongkar muat Tanjung Mas serta berada sekitar kapal-kapal tengker yang berlabuh menunggu giliran masuk ke Tanjung Mas. Waktu penelitian, cuaca cepat berubah dari mengambil sampel pagi dengan cuaca yang cerah hingga siang hari pengambilan sampel dengan angin yang kencang serta hujan. Meskipun pengambilan sampel pada pagi hari cerah, malam hingga fajar terjadi hujan di daerah laut Tambak Lorok sekitarnya yang dapat mempengaruhi pengukuran fisika kimia air laut serta hasil tangkapan.

Hasil penangkapan kerang darah di perairan laut Tambak Lorok saat pengambilan sampel pada bulan Oktober 2016 sesuai kebiasaan nelayan serta Februari 2017 untuk memperkaya informasi tentang kadar logam $\mathrm{Cu}$ dan $\mathrm{Cr}$. Penelitian ini mengalami sedikit permasalahan dengan sedikitnya hasil tangkapan karena ombak yang besar serta ekosistem hidupnya yang mulai rusak ditandai dengan banyaknya kerang yang mati saat penangkapan serta daerah penangkapan yang cukup jauh dari pesisir.

\section{Logam Berat, Fisika dan Kimia Perairan}

Kadar logam berat tembaga dan kromium perairan laut Tambak Lorok, Semarang meliputi 3 stasiun pada bulan Oktober 2016 dan Februari 2017 selengkapnya terdapat pada Tabel 3. sebagai berikut:

Tabel 3. Hasil Analisis Kadar Cu dan Cr di Perairan Tambak Lorok Semarang

\begin{tabular}{cccccccc}
\hline \multirow{2}{*}{ Waktu } & \multicolumn{2}{c}{$\begin{array}{c}\text { Stasiun I } \\
(\mathbf{m g} / \mathbf{L})\end{array}$} & \multicolumn{2}{c}{$\begin{array}{c}\text { Stasiun II } \\
(\mathbf{m g} / \mathbf{L})\end{array}$} & \multicolumn{2}{c}{$\begin{array}{c}\text { Stasiun III } \\
(\mathbf{m g} / \mathbf{L})\end{array}$} \\
\cline { 2 - 8 } & $\mathbf{C u}$ & $\mathbf{C r}$ & $\mathbf{C u}$ & $\mathbf{C r}$ & $\mathbf{C u}$ & $\mathbf{C r}$ \\
\hline Oktober 2016 & 0,001 & $<0,001$ & 0,002 & $<0,001$ & 0,002 & $<0,001$ \\
Februari 2017 & $<0,001$ & $<0,003$ & $<0,001$ & $<0,003$ & $<0,001$ & $<0,003$ \\
\hline
\end{tabular}

Kadar logam berat tembaga dan kromium pada sedimen perairan laut Tambak Lorok, Semarang meliputi 3 stasiun pada bulan Oktober 2016 dan Februari 2017 selengkapnya terdapat pada Tabel 4. sebagai berikut:

Tabel 4. Hasil Analisis Kadar Cu dan Cr pada sedimen di Perairan Tambak Lorok Semarang

\begin{tabular}{ccccccc}
\hline \multirow{2}{*}{ Waktu } & \multicolumn{2}{c}{$\begin{array}{c}\text { Stasiun I } \\
(\mathbf{m g} / \mathbf{k g})\end{array}$} & \multicolumn{2}{c}{$\begin{array}{c}\text { Stasiun II } \\
(\mathbf{m g} / \mathbf{k g})\end{array}$} & \multicolumn{2}{c}{$\begin{array}{c}\text { Stasiun III } \\
(\mathbf{m g} / \mathbf{k g})\end{array}$} \\
\cline { 2 - 7 } & $\mathbf{C u}$ & $\mathbf{C r}$ & $\mathbf{C u}$ & $\mathbf{C r}$ & $\mathbf{C u}$ & $\mathbf{C r}$ \\
\hline Oktober 2016 & 40,41 & 26,07 & 43,50 & 22,65 & 45,83 & 24,29 \\
Februari 2017 & 42,04 & 32,29 & 37,13 & 24,14 & 45,85 & 29,25 \\
\hline
\end{tabular}

Kadar logam berat tembaga dan kromium pada jaringan lunak A. granosa perairan laut Tambak Lorok, Semarang meliputi 3 stasiun pada bulan Oktober 2016 dan Februari 2017 selengkapnya terdapat pada Tabel 5. sebagai berikut: 
Tabel 5. Hasil Pengujian Kadar Cu dan Cr pada jaringan lunak A. granosa di Perairan Tambak Lorok Semarang

\begin{tabular}{ccccccc}
\hline \multirow{2}{*}{ Waktu } & \multicolumn{2}{c}{$\begin{array}{c}\text { Stasiun I } \\
(\mathbf{m g} / \mathbf{k g})\end{array}$} & \multicolumn{2}{c}{$\begin{array}{c}\text { Stasiun II } \\
(\mathbf{m g} / \mathbf{k g})\end{array}$} & \multicolumn{2}{c}{$\begin{array}{c}\text { Stasiun III } \\
(\mathbf{m g} / \mathbf{k g})\end{array}$} \\
\cline { 2 - 8 } & $\mathbf{C u}$ & $\mathbf{C r}$ & $\mathbf{C u}$ & $\mathbf{C r}$ & $\mathbf{C u}$ & $\mathbf{C r}$ \\
\hline Oktober 2016 & 0,43 & 0,64 & 0,86 & 0,71 & 1,48 & 0,56 \\
Februari 2017 & 1,46 & 0,65 & 1,26 & 0,44 & 1,24 & 0,70 \\
\hline
\end{tabular}
bawah ini :

Berat maksimum jaringan lunak A. granosa yang dikonsumsi tiap minggu ditampilkan di dalam Tabel 6 di

Tabel 6. Berat Maksimal Asupan Jaringan Lunak A. granosa yang Aman Dikonsumsi per Minggu (untuk Individu dengan Berat Badan Rata-Rata $60 \mathrm{~kg}$ )

\begin{tabular}{ccc}
\hline Logam Berat & Nilai MWI (gram/minggu) & Nilai MTI (gram/minggu) \\
\hline $\mathrm{Cu}$ & 0,210 & 0,187 \\
$\mathrm{Cr}$ & 0,001 & 0,002 \\
\hline
\end{tabular}

Hasil pengukuran parameter fisika kimia perairan laut Tambak Lorok, Semarang meliputi 3 stasiun pada bulan Oktober 2016 dan Februari 2017 selengkapnya terdapat pada Tabel 7. sebagai berikut:

Tabel 7. Kondisi Parameter Fisika Kimia Perairan Tambak Lorok Semarang

\begin{tabular}{cccccccc}
\hline & & \multicolumn{3}{c}{ Oktober 2016 } & \multicolumn{3}{c}{ Februari 2017 } \\
\cline { 3 - 8 } Variabel & Satuan & \multicolumn{3}{c}{ Stasiun } & \multicolumn{3}{c}{ Stasiun } \\
& & $\mathbf{1}$ & $\mathbf{2}$ & $\mathbf{3}$ & $\mathbf{1}$ & $\mathbf{2}$ & $\mathbf{3}$ \\
\hline Temperature & $\mathrm{C}$ & 28 & 30 & 30 & 29 & 31 & 31 \\
Salinitas air & $0 / 00$ & 25 & 27 & 31 & 25 & 28 & 30 \\
DO & $\mathrm{mg} / 1$ & 4,96 & 4,4 & 5,2 & 5,1 & 4,93 & 5,67 \\
pH air & - & 8 & 8 & 8 & 8 & 8 & 8 \\
Kedalaman & meter & 5 & 7,1 & 8,25 & 5 & 7,1 & 8,25 \\
Arus & $\mathrm{m} / \mathrm{s}$ & 0,11 & 0,07 & 0,09 & 0,09 & 0,08 & 0,14 \\
\hline
\end{tabular}

\section{Pembahasan}

\section{Kadar Logam Cu dan Cr pada Air}

Perairan Tambak Lorok Semarang memiliki kadar logam berat yang sangat rendah, baik logam tembaga maupun kromium. Nilai $\mathrm{Cu}$ dan $\mathrm{Cr}$ pada pengulangan ke 2 lebih kecil dari pada pengulangan pertama karena pada saat pagi sebelum pengambilan air sampel terjadi hujan. Meskipun memiliki nilai yang kecil tetap perlu diperhatikan, terutama pada kehidupan biota. Darmono (1995) dalam Rajiv (2016), bahwa konsentrasi logam dalam air memiliki hubungan yang erat dengan laju pertambahan kandungannya, tetapi hal tersebut tidak menjamin jika kandungan air mewakili kandungan logam berat pada jaringan.

Ketiga stasiun pada pengulangan I dan II memiliki hasil penelitian tembaga yaitu kurang dari $0,001 \mathrm{mg} / 1$ (1 $\mu \mathrm{g} / \mathrm{l})$ sampai $0,002 \mathrm{mg} / \mathrm{l}(2 \mu \mathrm{g} / \mathrm{l})$ di perairan Laut Tambak Lorok sedangkan pada penelitian Azhar et al. (2012) memiliki hasil 0,07 mg/l sampai 0,14 mg/l di perairan Wedung, Demak. Meskipun terletak sama pada perairan laut utara Jawa Tegah, tetapi memiliki hasil yang cukup jauh berbeda, dikarenakan Kecamatan Wedung terdapat 5,457 ha digunakan sebagai tanah pertanian disamping itu juga terdapat aktivitas dermaga, transportasi nelayan dan pembuatan kapal.

Berdasarkan hasil dari ke-3 stasiun dalam 2 kali pengambilan sampel, menggambarkan bahwa perairan laut Tambak Lorok masih sesuai dengan baku mutu untuk kehidupan biota laut. Menurut Kep.Men.LH nomor 51 tahun 2004 menyatakan bahwa batas maksimum logam berat $\mathrm{Cu} 0,008 \mathrm{mg} / \mathrm{l}$ dan $\mathrm{Cr}$ 0,005 mg/l. Semua stasiun telah diukur dan tidak ada yang melebihi batas. Persebaran logam berat dapat dipengaruhi oleh arus, kondisi asam basa perairan, suhu, kedalaman serta oksigen terlarut.

\section{Kadar Logam Cr dan Cu pada Sedimen}

Data hasil sampling menunjukan bahwa terakumulasinya logam $\mathrm{Cr}$ dan $\mathrm{Cu}$ pada ke 2 pengambilan sampel tidak terlalu jauh berbeda serta lebih banyak di sedimen dibandingkan yang terdapat di perairan. Banyaknya kadar logam berat kromium ini disebabkan sifat akumulatif dengan jangka waktu yang lama dan terus menerus pada sedimen yang mempunyai sifat relatif menetap, tidak bergerak pada daerah estuaria di lokasi penelitian (Suprapti et al,. 2008). 
Hasil penelitian pada stasiun 1 pada bulan Oktober 2016 dan Februari 2017 memiliki nilai yang tertinggi karena terletak berdekatan dengan daratan dan muara sungai tetapi memiliki kecepatan arus yang tinggi, meskipun memiliki arus yang tinggi, stasiun 1 berada di dekat aliran sumber pencemar. Menurut penelitian Setiawan et al. (2012), letaknya yang dekat dengan sumber pemasukan logam berat membuat konsentrasi logam $\mathrm{Cr}$ tetap tinggi meskipun terjadi proses pengadukan oleh arus perairan yang kuat.

Berdasarkan hasil pada bulan Oktober 2016 dan Februari 2017 menggambarkan bahwa logam berat kromium dan tembaga pada sedimen di perairan laut Tambak Lorok telah melampaui batas yang ditetapkan oleh NOAA dalam Buchman (1999) yaitu $0,052 \mathrm{mg} / \mathrm{kg}$ untuk kromium serta tembaga yaitu $0,019 \mathrm{mg} / \mathrm{kg}$.

\section{Kadar Logam Cu dan Cr pada Jaringan Lunak Anadara granosa}

Kadar tembaga tertinggi terletak di stasiun ke 3 pada bulan Oktober 2016, meskipun demikian hasil pengukuran dalam bulan Oktober 2016 maupun bulan Februari 2017 tidak terlalu jauh karena ukuran cangkang A.granosa dan hasil pengukuran faktor-faktor pendukung seperti temperature, salinitas, oksigen terlarut, $\mathrm{pH}$ serta arus tidak terlalu jauh. Menurut pendapat Maslukah (2013), menyatakan bahwa secara umum adanya perbedaan konsentrasi antara stasiun disebabkan oleh berbagai proses baik fisika, kimia ataupun biologi yang sangat berpengaruh pada proses pengendapan yang mejadi tempat hidup Anadara granosa. Ukuran cangkang A. granosa rata-rata 1-2 cm yang menurut Feriano et al. (2013) termasuk dalam ukuran kerang yang kecil. Cangkang kerang yang kecil memiliki akumulasi logam yang kecil. Pendapat tersebut diperkuat oleh Amriani et al. (2011), menyatakan bahwa semakin besar ukuran cangkang maka umur spesies tersebut juga diperkirakan lebih tinggi, sehingga waktu akumulasi berlangsung lebih lama dibandingkan kerang berukuran kecil.

Logam $\mathrm{Cr}$ dan $\mathrm{Cu}$ di dalam jaringan lunak $A$. granosa lebih rendah dari pada yang berada disedimen, karena $A$. granosa memiliki sistem ketahanan tubuh yang dapat mencerna dan membuang logam. Berdasarkan hasil penelitian dari Azhar et al. (2012), menyatakan bahwa kandungan logam berat $\mathrm{Cr}$ di perairan mempunyai ikatan yang kompleks sehingga sulit masuk ke dalam tubuh kerang anadara dan terjadinya pula proses eliminasi lewat feses urin.

Jaringan lunak $A$. granosa berhubungan secara langsung dan tidak langsung dengan perairan dan sedimen yang terdeteksi logam berat. Jaringan yang paling banyak terkena logam berat yaitu insang dan alat pencernaan yang langsung menyerap mineral-mineral air laut. Menurut Gosling (2004), menyatakan bahwa terdapat sebuah protein khusus (Metallothioneins) yang mengikat logam berat yang tersebar luas di jaringan seperti insang dan kelenjar pencernaan.

\section{Kelayakan Konsumsi Mingguan}

Tembaga adalah logam yang tergolong sangat dibutuhkan oleh tubuh meskipun dalam jumlah yang sedikit. Bila kandungan tembaga pada kerang yang dikonsumsi melebihi MWI (0,210 gram per minggu) bagi orang dengan berat badan $60 \mathrm{~kg}$ akan mengalami gejala keracunan seperti sakit perut, diare, serta dapat mengakibatkan gagal ginjal dan kematian. Menurut FAO (2011), keracunan $\mathrm{Cu}$ tingkat tinggi dapat menyebabkan gejala akut toksisitas, termasuk mual, ketidaknyamanan perut (diare), emesis (mual), hemoglobinuria (darah dalam urin), penyakit kuning, oliguria atau anuria (gangguan ginjal), hipotensi, koma dan kematian.

Kromium adalah logam yang sering digunakan untuk mengobati kulit manusia yang berupa kristal asam khromat, tetapi sering kali berakibat keracunan (Palar,1994). Jika kandungan kromium pada kerang yang dikonsumsi melebihi MWI (0,001 gram per minggunya) bagi orang dengan berat badan $60 \mathrm{~kg}$ akan mengalami kerusakan pada organ percernaan, pernafasan. Hal tersebut didukung oleh Widowati et al. (2008), menyatakan bahwa mencerna makanan yang mengandung $\mathrm{Cr}$ tinggi dapat menyebabkan sakit lambung, luka pada lambung, kerusakan pada ginjal dan lepar, serta efek toksis pernafasan akan menurunkan fungsi paru-paru, asma.

Seluruh kadar tembaga dan kromium pada jaringa lunak A. granosa di perairan laut Tambak lorok Semarang diambil rata-rata, untuk tembaga 0,210 gram per kilogram daging kerang serta kromium 0,001 gram per kilogram daging kerang. Sehingga untuk nilai MTI tembaga, orang dengan berat $60 \mathrm{~kg}$ dapat mengonsumsi sebanyak 0,187 gram per minggu serta MTI kromium dengan mengkonsumsi tidak boleh lebih dari 0,002 gram per minggu.

\section{Parameter Fisika dan Kimia}

Temperature merupakan salah satu parameter fisika yang penting. Perubahan temperature di perairan dapat mempengaruhi sifat fisika kimia biologi biota laut serta distribusi logam berat. Temperature pada ke 2 periode bekisar antara $28^{\circ} \mathrm{C}-31^{\circ} \mathrm{C}$. Perbedaan suhu pada bulan Oktober 2016 pada stasiun 1 lebih rendah terpengaruh adanya kapalkapal tengker yang membawa kayu serta batu bara pada stasiun 2 dan 3. Bulan Februari 2017, stasiun 1 memiliki suhu yang lebih rendah dari stasiun 2 dan 3. Pengambilan data pada periode ke 2 ini tidak terdapat kapal-kapal tengker tetapi pada saat pagi terjadi hujan deras yang tidak begitu lama. Menurut Eshmat et al. (2014), menyatakan bahwa temperature perairan mempengaruhi proses kelarutan logam berat yang masuk ke perairan. Nilai dari kedua periode tersebut tidak jauh dari hasil penelitian Taurusiana et al. (2014), dimana temperature perairan laut sekitar Tambak Lorok $29,2-30,1^{\circ} \mathrm{C}$.

Salinitas dapat mempengaruhi kadar logam berat di perairan, bila terjadi penurunan salinitas maka akan menyebabkan peningkatan daya toksik logam berat dan tingkat bioakumulasi logam berat semakin besar (Erlangga, 2007). Hal ini sesuai dengan hasil penelitian pada perairan laut Tambak Lorok berkisar $25 \% 00-31 \%$. 
Oksigen terlarut merupakan faktor pembatas bagi kehidupan biota pada perairan bebas. Nilai DO yang cenderung rendah pada stasiun 2 pada bulan Oktober 2016 karena adanya bahan organik di perairan. Sedangkan nilai DO pada stasiun 3 pada bulan Februari 2017 lebih tinggi karena dipengaruhi oleh kecepatan arus serta angin. Berdasarkan Kep. Men. L.H nomor 51 tahun 2004, nilai DO pada stasiun 1 dan 2 bulan Oktober 2016 serta stasiun 2 bulan Februari 2017 tidak memenuhi batas aman bagi kehidupan biota. DO merupakan parameter kunci untuk menentukan pencemaran perairan (Ginting et al., 2014) serta nilai oksigen terlarut rendah akan meningkatkan risiko akumulasi logam berat pada organisme perairan (Indrawati et al., 2015). Hal tersebut juga didukung oleh Eshmat et al.(2014), semakin besar nilai DO pada air, mengindikasi air tersebut memiliki kualitas yang bagus. Sebaliknya jika nilai DO rendah, dapat diketahui bahwa air tersebut telah tercemar.

Nilai $\mathrm{pH}$ mempengaruhi besar daya larut logam, jika nilai $\mathrm{pH}$ basa maka logam berat akan larut dalam perairan dan organisme akan lebih mudah mengabsorbsi logam berat didalam tubuhnya, sedangkan $\mathrm{pH}$ rendah (asam) maka logam berat sukar larut dalam perairan dan akhirnya mengendap dalam sedimen(Rochyatun dan Rozak, 2007). Derajat keasaman pada perairan umunya relatif konstan dan mendekati netral. Hal ini dikarenakan air adalah penyangga kehidupan biota air serta $\mathrm{pH}$ akan berubah jika ada pembuangan limbah organik secara terus menerus. $\mathrm{pH}$ hasil pengukuran semua stasiun dalam 2 pengulangan di perairan laut Tambak Lorok adalah 8.

\section{KESIMPULAN}

Berdasarkan hasil penelitian yang telah dilakukan di perairan Laut Tambak Lorok Semarang, dapat disimpulkan bahwa:

1. Kadar logam $\mathrm{Cu}$ berkisar kurang dari $0,001 \mathrm{mg} / \mathrm{l}$ sampai $0,002 \mathrm{mg} / \mathrm{l}$. Kadar logam Cr memiliki kisaran nilai kurang dari 0,001 mg/l sampai kurang dari 0,003 mg/l. Kadar tersebut belum melampaui baku mutu;

2. Kadar logam Cu pada sedimen dengan kisaran $37,13 \mathrm{mg} / \mathrm{kg}$ sampai $45,85 \mathrm{mg} / \mathrm{kg}$. Sedangkan pada kadar logam $\mathrm{Cr}$ yaitu 22,65 mg/kg sampai 32,29 mg/kg. Kadar logam berat pada sedimen lebih tinggi daripada yang berada pada perairan, logam kromium melebihi ambang batas serta logam tembaga belum melampaui ambang batas;

3. Kadar logam Cu pada Anadara granosa adalah $0,43 \mathrm{mg} / \mathrm{kg}$ sampai $1,48 \mathrm{mg} / \mathrm{kg}$. Sedangkan pada logam $\mathrm{Cr}$ memiliki kisaran nilai $0,44 \mathrm{mg} / \mathrm{kg}$ sampai $0,70 \mathrm{mg} / \mathrm{kg}$. A. granosa telah tercemari oleh logam berat pada perairan Tambak Lorok;

4. Kelayakan konsumsi (Maksimum Tolerable Intake) pada Anadara granosa yaitu 0,187 gram per minggu untuk logam $\mathrm{Cu}$ dan $\mathrm{Cr}$ bernilai 0,002 gram per minggu.

\section{UCAPAN TERIMAKASIH}

Ucapan terimakasih ditunjukan kepadaWiwiet Teguh T., S.Pi., M.Si. yang telah memberikan masukan, kritik dan saranyang sangat berarti bagi penulis.

\section{DAFTAR PUSTAKA}

Amriani, B. Hendrarto dan A. Hadiyarto. 2011. Bioakumulasi Logam Berat Timbal (Pb) dan Zeng (Zn) pada Kerang Darah (Anadara granosa L.) dan Kerang Bakau (Polymesoda bengalensis L.) di Perairan Teluk Kendari. Jurnal Ilmu Lingkungan., IX(2): 45-50.

Anggraini, A.S. 2016. Preparasi dan Karakterisasi Limbah Biomaterial Cangkang Kerang Darah (Anadara granosa) dari Pantai Muara Gading Mas sebagai Bahan Dasar Biokeramik [Skripsi]. Universitas Lampung, Lampung, $55 \mathrm{hlm}$.

Azhar, H., I. Widowati dan J. Suprijanto. 2012. Studi Kandungan Logam Berat Pb, Cu, Cd, Cr pada Kerang Simping (Amusium pleuronectes), Air dan Sedimen di Perairan Wedung, Demak serta Analisis Maksimum Tolerable Intake) pada Manusia. Journal of Marine Research., I(2): 35-44 2012.

APHA. 1992. Standart Method for The Examination of Water andWastewater. $18^{\text {th }}$ edition. Washington, $2552 \mathrm{p}$.

Buchman, M. 1999. http://www.gesamp.org/ QuiRTs. Restoration. Noaa. Gov/ cpr/ Sediment quirt.pdf. Browse from Google. 07 Maret 2017.

Erlangga. 2007. Efek Pencemaran Perairan Sungai Kampar di Provinsi Riau terhadap Ikan Baung (Hemibagrusnemurus).[Tesis]. Program Studi Pengelolaan Sumberdaya Pesisir dan Laut. Institut Pertanian Bogor. Bogor. 80 hal.

Eshmat, M. E., G. Mahasri dan B. S. Rahardja. 2014. Analisis Kandungan Logam Berat Timbal (Pb) dan Cadmium (Cd) pada Kerang Hijau (Perna viridis L.) di Perairan Ngemboh Kabupaten Gresik Jawa Timur. Jurnal Ilmiah Perikanan dan Kelautan., VI(1): 101-108.

FAO/WHO. 2004. Summary of Evaluations Ferformade by the Jint FAO/WHO Expert Committee of Food Additives (JECFA 1956-2003). ILSI Press nternational Life Sciences Institute.

FAO Fisheries and Aquaculture. 2011. Joint FAO/WHO Food Standards Programme Codex Committee on Contaminants in Foods. Codex Alimentarius Commision. 89 p.

Feriano, H.B., C. Adhi S dan B. Yulianto. 2013. Sebaran Kerang Anadara granosa Berdasarkan Kelas Ukuran Terhadap Logam Berat Cr (Chromium) Di Perairan Pantai Semarang Bagian Timur. Journal of Marine Research., II(3): 85-94. 
Ginting, A., P. Patana dan Nurmatias. 2014. Kandungan Logam Berat Timbal (Pb) pada Air, Sedimen dan Kerang Darah (Anadara granosa) di Pantai Belawan, Provinsi Sumatera Utara. Universitas Sumatera Utara., I(1): 2432.

Gosling, E. 2004. Bivalve Molluscs: Biology, Ecology and Culture. Great Britain: MPG Books Ltd, Bodmin, Cornwall. $443 \mathrm{p}$.

Indrawati, E., D. Arfiati, Marsoedi and E. Y. Herawati. 2015. Path Analysis of Plumbum (Pb) Accumulation in the Remis (Corbicula javanica) in the Maros River, Indonesia. International Journal of Recent Scientific Research., 8(6): 5711-5716.

Keputusan Menteri Negara Lingkungan Hidup Nomor 51 Tahun 2004 tentang Baku Mutu Air Limbah.

Latimer, G.W. 2012. Official Methods of Analysis of AOAC International. Gaithersburg, MD, USA.

Maslukah, L. 2013. Hubungan antara Konsentrasi Logam Berat Pb, Cd, Cu, Zn dengan Bahan Organik dan Ukuran Butir dalam Sedimen di Estuari Banjir Kanal Barat, Semarang. Buletin Oseanografi Marina., II(2): 55-62.

Palar, H. 1994․ Pencemaran dan Toksikologi Logam Berat. Jakarta: Rineka Cipta.148 hlm.

Palar, H. 2008 . Pencemaran dan Toksikologi Logam Berat. Jakarta: Rineka Cipta.152 hlm.

Partogi, M.A., P.W. Purnomo dan Suryanti. 2014. Distribusi Logam Berat Timbal (Pb) dan Cadmium (Cd) di Sedimen, Air dan Bivalvia di Lingkungan Muara Sungai Wiso Jepara. Diponegoro Journal of Maquares Management og Aquatic Resources., III(4): 92-101.

Rajiv, A, 2016. Analisis Biomagnifikasi Logam Berat Pb dan Cd di Perairan Tambak Lorok Semarang. [Skripsi]. Fakultas Perikanan dan Ilmu Kelautan, Universitas Diponegoro, Semarang. $51 \mathrm{hlm}$.

Rochyatun, E. dan A. Rozak. 2007. Pemantauan Kadar Logam Berat dalam Sedimen di Perairan Teluk Jakarta. Makara, Sains., XI(1): 28-36.

Setiawan, K., L. Maslukah dan R. Pribadi. 2012. Konsentrasi Logam Berat Khromium (Cr) pada Air, Sedimen dan Kerang Darah (Anadara granosa) di Perairan Sungai Morosari dan Suangai Gonjol Kecamatan Sayung Kabupaten Demak. Journal of Marine Research., I(1): 29-28.

Suprapti, N. H. 2008. Kandungan Chromium pada Perairan, Sedimen dan Kerang Darah (Anadara granosa) di Wilayah Pantai Sekitar Muara Sungai Sayung Desa Morosari Kabupaten Demak, Jawa Tengah. Bioma., X(2) :36-40.

Taurusiana, S., N. Afiati dan N. Widyorini. 2014. Kajian Kandungan Logam Berat Besi (Fe) dan Seng (Zn) pada Jaringan Lunak Kerang Darah (Anadara granosa(L.)) di Perairan Tanjung Mas, Semarang dan Perairan Wedung, Demak. Diponegoro Journal of Maquares Management of Aquatic Resources., III(1): 143-150.

US. EPA (United Stated Environmental Protection Agency). 1996. SW-846 Test Method 3050B: Acid Digestion of Sediments, Sludges, and Soils. https://www.epa.gov/hw-sw846/sw-846-test-method-3050b-acid-digestionsediments-sludges-and-soils. Browse from Google. 01 April 2017.

Widowati, W., A. Sastiono dan R. Jusuf R. 2008. Efek Toksik Logam, Pencegahan dan Penanggulangan Pencemaran. Yogyakarta: Andi Offset. $410 \mathrm{hlm}$.

Zazouli, M. A., M. Shokrzadeh., A. Mohseni and E. Bazrafshan. 2006. Study of Chromium (Cr) Concentration in Tarrom Rice Cultivated in the Qaemshahr Region and its Daily Intake. World Applied Sciences Journal., 1(2) :60-65. 